\title{
ПИСМА ИЗ ПЕТРОГРАДА РАДОВАНА КОШУТИЋА
}

\begin{abstract}
У раду се анализира Кошутићева културолошка студија, објављена у 24 писма у Просветном гласнику од 1891. до 1895. Настала је у Петрограду где је Кошутић, током и непосредно по завршетку студија славистике, провео неколико година, бавећи се темељнијим изучавањем руског језика и културе. У пуном обиму овај Кошутићев рад до сада није био предмет истраживања.
\end{abstract}

Кључне речи: Радован Кошутић, Писма из Петрограда, Просветни гласник, културолошко наслеђе.

The paper analyses Košutić's cultural study, published in 24 letters in the Prosvetni Glasnik from 1891 to 1895. It originated in Saint Petersburg, where Košutić spent several years during and shortly after completing his Slavic studies, studying more thoroughly the Russian language and culture. To the full extent, this work by Košutić work has not been the subject of research so far.

Keywords: Radovan Košutić, Letters from Petrograd, the Prosvetni Glasnik, cultural heritage.

Један од најзначајнијих српских слависта двадесетог века, Радован Кошутић (1866-1949) током студија и као тек дипломирани слависта, боравио је у Петрограду ради проучавања руског језика, књижевности и руске културе. Наиме, студије словенских језика и књижевности на Филозофском факултету у Бечу Кошутић је уписао у јесен 1885., а као студент провео је два семестра у Прагу, један у Кракову, три у Лавову и школску 1889/90. годину као ванредни слушалац у Петрограду. Дипломирао је 1890. године у Бечу, али већ у јесен те исте године поново је у Петрограду, где је боравио дуже од три године. Управо у том периоду настала су његова Писма из Петрограда, која је од 1891. до 1895. периодично објављивао Просветни гласник, као изворне дописе, упућене овом еминентном часопису Министарства просвете Србије. Ова културолошка студија, објављена у 24 наставка (писма), прво је Кошутићево обимно прозно дело и јединствено у читавом његовом књижевном и научном опусу. Као пишчева издања, на основу ових прилога, објављене су две књиге: Писма из Петрограда (Београд, 1895) и Нова писма из Петрограда (Београд, 1896). Кошутић је у ове књиге укључио укупно 16 писама, док је од преосталих осам намеравао да објави трећу књигу под називом Последюа писма из Петрограда, што је најавио на почетку друге књиге, дајући попис својих дотадашњих радова. Међутим, доласком на Велику школу, он се потпуно посвећује новом позиву. «Ретки су данас књижевници који пишу с толико фактичког знања о изабраном предмету, <..> но осим знања ми тражимо од писца, био он песник, научник или публицист, да је свестан свога позива и да истрајно служи некој идеји; од наших принципа зависи, да ли ћемо се сложити с њим; али сам факат, да из њега говори убеђење мора изазвати у нама осећај поштовања према њему, поштовања, што га одаје убеђен човек убеђеном» (Кошутић 1892: 224). Управо с оваквим уверењем писао је Кошутић своја Писма 
и са истом преданошћу окреће се нешто касније наставничком раду, стварању научно-наставне литературе у области русистике, полонистике и бохемистике, утемељењу нове лингводидактичке парадигме, те је разумљиво да је одустао од припреме и објављивања треће књиге. Разуме се, разлог одустајања могао је бити и финансијске или неке друге природе.

Раду на студији претходило је Кошутићево поетско стваралаштво сажето у збирке стихова Пламенови I (Нови Сад, 1888), Пламенови II (Нови Сад, 1890), Пламенови III (Нови Сад, 1892), Синови Бога Мрака (Пламенови IV), спев (Београд, 1893). Истовремено, Кошутић се бави проучавањем нових праваца у књижевној критици и објављује студије Критика и књижевност (Београд, 1893) и Узроци препорођају књижевне критике (Београд, 1894). Обе студије наишле су на оштру критику двојице угледних научника, прва В. Јагића (1948: 520), друга Б. Поповића (Просветни гласник 1895: 266-7). Као одговор на критику Б. Поповића настао је чланак $У$ одбрану студије «Узрочи препорођају књижевне критике» (Београд, 1895). Од већих радова, насталих пре Кошутићевог доласка на Велику школу, запажен је његов приказ Историје руске етнографије А.Н. Пипина, објављен у пет наставака у Просветном гласнику (даље ПГ) за 1892. годину.

Почетак Кошутићевог научног рада у области словенских језика везан је за његов долазак на Велику школу, тада највишу образовну установу у земљи, првог јануара 1895. године, пуне четири године након дипломирања. Инспирисан потребама наставе Кошутић ствара своја ремек-дела из области руског и пољског језика и књижевности. Као оквирни период његовог научног рада у овој области К. Тарановски наводи раздобље од 1895 до 1920. године, а као признања за високе домете добио је почасни докторат Краковског универзитета, изабран је за дописног члана Академије наука Совјетског Савеза (2. фебруара 1928), а 1929. године изабран је за дописног члана Словенског института у Прагу. (Тарановски 1949/50: 514). Крајње неповољни међудржавни односи у периоду између два светска рата (немогућност боравка у Русији, мали број студената, финансијски проблеми око штампања књига и др.) нису погодовали даљем раду у овој области, те се Кошутић враћа песничком раду и већ 1923. објављује нову збирку поезије. Према подацима Р. Константиновића, који је први у нашој књижевности анализирао и описао Кошутићев песнички опус, у периоду од 1927. до 1941. године објавио је 16 збирки поезије (Константиновић 1983, књ. 4: 207). Стога је природно да је последње Кошутићево научно дело О тонској метрици у новој српској поезији (Београд, 1941) посвећено науци о српском стиху.

1.

У Напомени на почетку прве књиге Кошутић наводи да су Писма излазила у Просветном гласнику од јануара 1892. године. Међутим, у књигу су укључена и посебно нумерисана четири чланка $O$ народној просвети у Русији која су објављена у последње две свеске за 1891. и прве две за 1892. годину истог часописа. Ова четири писма не разликују се од осталих, па је тешко закључити због чега их је сам аутор издвојио. Може се претпоставити да је Кошутић овим прилозима желео допринети тада веома актуелној реформи наставе страних језика. 
Наиме, у намери да осавремени наставу Министарство просвете упутило је у Петроград, Париз и Беч неколико гимназијских професора, да проуче школске системе тих земаља. Светислав Симић и Милутин Драгутиновић, професори учитељске школе и гимназије боравили су у Петрограду, а њихови извештаји (О руским средюим школама, Васпитање у руским школама) објављени су у Просветном гласнику за 1892. годину (дет. Дамљановић 2000: 135). Кошутић, будући да се већ налазио у Петрограду, одазвао се поменутим чланцима. Док су Драгутиновић и Симић «на основу похађања овдашњих гимназија и проучавања литературе» описали савремено стање, Кошутић је дао широку слику историје школства у Русији. Имајући у виду формално-структурну подударност издвојених прилога са осталим прилозима, као и чињеницу да их је Кошутић равноправно уврстио у прву књигу, сматрамо ова четири писма интегралним делом студије објављене у ПГ.

Оцењујући рецепцију Кошутићевог лингводидактичког наслеђа у периоду после Другог светског рата, К. Кончаревић наводи да су српски и југословенски слависти објавили о њему у домаћим и страним публикацијама више прилога него о било ком домаћем или страном русисти (Кончаревић 2016: 358). Исто тако његови савременици из целог словенског света високо су оценили дела из области лингвистичке русистике (Терзић 1986, Дамљановић 2000: 126-129). Па ипак Писма из Петрограда у целини, у обиму како су објављена у Просветном гласнику, остала су ван интересовања стручне и научне јавности. У радовима Р. Лалића (Лалић 1963) и Б. Терзића (Терзић 2006) говори се о књигама Писма из Петрограда и Нова писма из Петрограда; чињеница је да трећина укупних текстова студије није уврштена у поменуте књиге.

И Р. Лалић и Б. Терзић оценили су да се ради о веома темељном делу. Дајући сажету слику проблематике којом се бави Кошутић, Лалић закључује: «Ово дело показује да се Кошутић ... врло озбиљно бавио изучавањем Русије, њене историје и културе» (1963: 382). У закључку анализе културолошког аспекта ових књига Б. Терзић наводи да је пред нама „аналитичка студија многих страна живота Русије, али и Србије. То значи да се ради о књигама, методолошки заснованим на културолошкој конфронтацији двају народа, двеју држава. А крајњи циљ је упознавање српске читалачке публике са стањем и достигнућима у процесима друштвеног развоја генетски и историјски блиског руског народа“ (2006: 30).

Већ крајем 1894. године Кошутић је објавио прву књигу, о чему сведоче два податка у ПГ: обавештење о новим издањима и записници седница Главног просветног савета. У рубрици Нове књиге у броју 12 за 1894. годину налазимо кратак приказ прве књиге (ПГ 1894: 856). На 609. седници од 28. XII 1894. Савет је одлучио да се књига Писма из Петрограда откупи и препоручи за библиотеке средњих школа. О другој књизи расправљало се на 647. седници Савета од 10. новембра 1895. и одлучено је да се дело Нова писма из Петрограда откупи за поклањање на испитима ученицима средњих школа.

Приликом састављања књига Кошутић се превасходно руководио тематским критеријумом, а не редоследом објављивања прилога у ПГ. У прву књигу уврштена су четири писма посебно нумерисана (О народној просвети у Русији), затим III и V (објављено у ПГ за 1892), VI, VII, VIII (ПГ за 1893) и XVI писмо 
(ПГ за 1894.). У другу књигу уврштено је IX, X, XI, XII, XV (у књизи дато као два писма: шесто и седмо) и XVII писмо (ПГ за 1894). Ван књига остала су I, II, IV писмо (ПГ за 1892), XIII, XIV (ПГ за 1894), XVIII, XIX и XX (ПГ за 1895).

Структура Писама је једнообразна: после наслова Писма из Петрограда следи редни број прилога, затим анонс са детаљним садржајем. Код појединих писама у анонсу је издвојена главна тема, у другим случајевима није. Код већине прилога разликује се документарни део заснован на различитим изворима и део који садржи Кошутићеве коментаре, запажања, описе и слично. Ово последње најчешће је издвојено на почетку или на крају прилога и управо ти делови су предмет наше детаљније анализе. Често нису повезани с основном темом, те су у књигама или премештени уз друге прилоге (нпр. петроградске теме) или изостављени (нпр. делови који садрже критику стања у Србији).

Суштину Писама сажео је сам аутор на почетку предговора у првој књизи: «Бавећи се неколике године у престоници на Њеви, писац је бележио сваку значајнију појаву на пољу културног живота руског, у намери да ближе упозна своје земљаке са братским нам руским народом, са племенитом му тежњом за књигом и напретком, са пуним пожртвовања напорима просвећених синова и кћери руских, да изађу на сусрет тој тежњи његовој, најзад са разним препрекама, које коче тај красни рад, изазивајући нове жртве и нова пожртвовања. Ако читалац, прочитав Писма из Петрограда, научи разликовати светле стране руског живота од тамних, и ценећи и љубећи у Русији оно што је у истини достојно сваког поштовања, хвале и дивљења, прегне да и ми пођемо новим путем, књига је достигла циљ, ком је циљнула».

Као изворе информација Кошутић је користио најновију научну и стручну литературу, књижевна дела, монографије, путописе, биографску литературу, педагошку литературу, званичне извештаје, статистичке податке, расправе и студије, импозантан број новина и часописа (Руска школа, Ново време, Новости, Гласник Јевропе, Руски гласник, Казански гласник, Смоленски гласник, Жива старина, Руска старина, Сеоски гласник, Цар-колокол, Свет, Московски листак, Московске новине и др). Занимљиво је да називе новина и часописа у ПГ Кошутић наводи на руском језику, док у књигама користи превод.

Књига Писма из Петрограда (1895) упознаје српског читаоца са тегобним и дуготрајним радом на описмењавању, образовању и просвећивању сеоског становништва и сиромашних слојева руског друштва. Разматра се историјски развој и савремено стање народног образовања у Русији, како институционалног, тако и ванинституционалног. У књизи Нова писма из Петрограда (1896) разматрају се три основне теме: Из прошлости руске цензуре, Први руски слависти у нашим крајевима, Листак из историје руских универзитета. Као централна тема најављене треће књиге остала је тема религије и свештенства која се разматра у шест од укупно осам писама.

2.

Проблем описмењавања најширих слојева друштва, њихово просвећивање и образовање, оснивање и рад основних школа (слободне сељачке школе, црквенопарохијалне и манастирске школе, школе министарства просвете, школе локал- 
них заједница), рад недељних школа, школа за образовање девојака, ваншколско описмењавање и образовање, све то се разматра у четири издвојена писма под називом $O$ народној просвети у Русији. Ови текстови су, према речима Кошутића, «пабирци по књизи А.С. Пругавина», објављеној у Москви 1890. године. Различити облици образовања и просвећивања народа, рад угледних школа и истакнутих појединаца, оснивање и рад библиотека и читаоница, издавачка делатност, дистрибуција издања за народ по селима и мањим местима, јавна читања, све то чини садржај прве књиге Писама, јер «имати с једне стране велику књижевност, имати Пушкина, Гогоља, Тургењева, Толстоја, а с друге - народ који каменује лекаре и види у просвећеним људима своје крвне непријатеље, без сумње је трагичан положај за сваког образованог сина његовог» (Кошутић 1895: 168).

Одвајајући рад државе од рада појединаца, интелигенције и представника народа на просветном пољу и описмењавању сеоског становништва, Кошутић je сву пажњу усмерио управо на последње. Стога он са посебним надахнућем пише о слободним сељачким школама или домаћим школама писмености, како је њихов званични назив, које су, уз црквене и манастирске школе, биле најстарије образовне установе у Русији. Ове школе створила је «брига руских сељака, да просвете себе и децу своју». Биле су веома бројне и биле су расадници народног образовања: «Ко не води рачуна о њима, превиђа једну од најзанимљивијих и најлепших појава руског народног живота» (Кошутић 1895: 3-4). Оснивали су их често у својим домовима сами сељани, а учитељи су били писмени сељаци или ислужени војници. Поред црквених и манастирских школа, слободне сељачке школе помињу се у летописима од 13. века, а постојале су до краја 19. века, дакле пуних седам векова. «Сем огромне користи, што су доносиле и доносе, сем милијуна којима су дале прву храну душевну, слободне сељачке школе су и најбољи доказ, како руски народ цени просвету и како је висок појам о снази њезиној, доказ оне тежње за светлошћу, коју гаје милијуни руских мужика у најудаљенијим крајевима те велике државе. Ко је тако жедан просвете, ко откида од крваве зараде своје, да даде очни вид детету свом, ко се тако радује, кад има школу и тако тужи за њом, кад је нема: тај показује да јој разуме значај. Ретка појава, коју ћете ретко наћи код других народа. Те су школе уједно и најбољи одговор онима, који замишљају руског сељака као звер, а унутрашњост Русије као пустињу, у којој влада вековна тишина. Тамо су све животне клице у развићу, треба само вично око, да их запази» (Кошутић 1895: 20).

Почетак ширих активности државе на описмењавању сељака везан је за укидање кметства (1861) и посебно за период после царског указа из 1864. којим се уводи општинска самоуправа и право локалних заједница да отварају своје школе, тзв. "'земске", а у градовима, градске школе. У исто време отварају се многобројне црквено-парохијалне школе у којима су предавали сеоски свештеници и свршени ученици средњих духовних школа. Кошутић придаје велики значај овоме периоду: «Реформа из 1861. године, ослободивши мужицима тело из тешког ига крепосног права, чека на сличну реформу, која би им ослободила дух од окова таме и незнања. Друга била би достојна прве, ако не и већа од ње» (1895: 94). 
Јавна читања и предавања као облици просвећивања и образовања народа организована су под надзором управника народних школа, а избор књига вршио је Просветни савет и Свети Синод, свако из своје сфере надлежности. Јавна читања су била отворена за све заинтересоване слушаоце; одржавана су у музејима, школама, народним кухињама, док су читања затвореног типа организована у касарнама, болницама, казненим заводима и фабрикама. Једном таквом предавању одржаном 15. марта 1892. у Педагошком музеју у Петрограду присуствовао је и сам Кошутић и уверио се, колико су она популарна и добро посећена. Сала капацитета 500 седишта била је пуна, а о посетиоцима не без књижевних претензија Кошутић пише: «У првом реду седе господа, а за њиховим леђима почиње одмах она мешавина од неколико стотина лица из разних сталежа, - мешавина, коју ћете наћи само у црквама и на читањима за народ. Гимназисти у својим беличастим капутима, студенти с плавом огрлицом и узаним университетским сабљама, војници разних пукова, пуни трговци и мршави им помоћници, плаве девојчице сањалачког лица, вредни радници црних руку, старци с унучићима, матере с ћеркама - све се то слило у једну целину, и мирно чека да отпочне предавање. Дивио сам се понашању њиховом. То није улична светина, која је дошла да блене, да се смеје, да време утуче. Већина их има неколико часова слободног времена, па већ то, што је дошла да га проведе у поуци, сведочи да јој разуме значај» (Кошутић 1895: 104-5). Значај оволиког интересовања и посећености је утолико већи, ако се има у виду да је Музеј организовао читања за народ и јавна предавања два пута недељно: четвртком духовног и недељом световног садржаја.

Велико интересовање најширих слојева руског друштва за читање довело је до отварања библиотека и читаоница по градовима и селима, до појаве великог броја издавача и дистрибутера популарне литературе, као и до покретања међу интелигенцијом живе расправе о томе, шта читати народу. Кошутић је за српске читаоце пренео мишљења Пругавина, Мичурина и Толстоја о тој теми. Анализирајући духовну (житија, псалтире, часловце, јеванђеља, молитвенике, приче духовно-поучног садржаја) и световну литературу (бајке, приповетке, романе, историјске књиге, песмарице, сановнике, календаре), Кошутић жали што ова литература «истискује оне лепе песме које је народ сам спевао и руска народна лирика лишила се својих најлепших црта» (1895: 58-9). Подвлачећи значај овога начина образовања Кошутић даље истиче: «Књига је почела спремати руског мужика за борбу у животу, само што је време тако кратко било, да он није могао још ни прекорачити прага оном дивном просветном храму, у који је руски ум унео толико величанствених дела, толико светлих мисли на понос себи и човечанству, а није знао увести у њ руског сељака» (1895: 94).

Примере успешне примене оба начина просвећивања као и значај појединца у том процесу показан је кроз прилог о раду Женске недељне школе у Харкову, који је написан на основу чланака објављених у часопису Руска школа (1892, бр. 7-8) и монографије о раду те школе Ј. В. Абрамова. Од оснивања 1862. године, заслугом Христине Даниловне Алчевске, школа је окупљала девојке и жене старије од 14 година, а са њима, по индивидуалним програмима, бесплатно су радиле надахнуте наставнице. У свом саставу школа је имала педагошки музеј и ђачку библиотеку, а Алчевска је водила педагошки дневник о раду 
сваке ученице. Школа је организовала јавна читања за своје ученице и сеоско становништво, а на основу њихове реакције прилоком читања дела руских и светских писаца настала је књига обима око две хиљаде страна - Шma да се чита народу. У Русији ова књига је примљена као извор «за познавање интелектуалне висине руског сељака, а учени људи на Западу запазише у њој нешто сасвим ново. Књига доби на последњој париској изложби највишу награду академску палму, и прослави се» (Кошутић 1895: 143). Из ове књиге Кошутић је превео запажања о рецепцији дела Пушкина, Гогоља, Островског и Шекспира. Одличне реакције и дубоко разумевање ове публике имала је Гогољева приповетка Шињел као и Бура Островског. Исто тако ученице женске школе одлично су разумеле Хамлета, док Евгеније Оюегин није читан, јер испразан живот Пушкиновог јунака, по мишљењу публике, није био довољно уверљив.

Колико појединац може допринети напретку заједнице види се кроз поглавље о Н. В. Каразину (1773-1842), оснивачу универзитета у Харкову и првом министру просвете у тек установљеном министарству у време владавине Александра I. Био је српског порекла, а опширно поглавље о његовој друштвеној, академској и научној делатности Кошутић пише на основу монографије Ј. В. Абрамова, објављене 1891. године. Поред њега, помиње се министар финансија Кнежевић који је „први изнео у јавност руски државни буџет и дао штампи слободу да поведе реч о њему“. Њихове биографије, према Кошутићу, служе као доказ „како је даровита била она шака Срба, што утону у руско море“ (ПГ 1893: 356).

Многобројни примери ангажовања појединаца, посебно девојака и жена, у описмењавању народа, отварању читаоница, библиотека и недељних школа, приређивању читања за народ, подстакло је Кошутића да се обрати српским женама: «Српске госпођице и госпође, које сте се училе по нашим и туђим школама, ето рада достојна просвећености ваше. Угледајте се на те врле Рускиње, прегните на посао, да не огрезнете у блату општег немара нашег» (1895: 91).

Образовање и просвећивање народа најчешће се наводи као најделотворније средство у борби против примитивизма, празноверја, пијанства који још увек царују међу сеоским становништвом. У тој борби важну улогу може одиграти појединац, што илуструје пример Ивана Филатова, бившег фабричког радника, који је читањем преобразио једно руско село, од села туча и пијанства у успешно и напредно село (Кошутић 1895: 173). Вођен примером Филатова Кошутић закључује да се „из овога најбоље види, како књига благотворно утиче на руско село; он нам улива наду да ће она временом уништити <... > не само зверске трагове празноверице, већ да ће сломити и онај бич који шиба од векова руског сељака, удавити ону гују која му пије крв и мозак - да ће искоренити пијанство» (ПГ 1892: 818).

3.

Прва од три теме друге књиге - Из прошлости руске цзензуре - написана је на основу истраживања А. М. Скабичевског (Очерки истории русской цензуры /1700-1863/, Спб, 1892), обављеног на корпусу званичних докумената. На основу ове књиге Кошутић пише о раду цензора Ф. О. Туманског, «представника једне мрачњачке епохе» и А. В. Красовског: «Тешко је замислити другог који 
би се с тако слепом и тупом ревношћу подвлачио под дух времена» (1896: 25, 5). На удару цензуре била су домаћа и страна књижевна дела, новине и часописи, уџбеници; будно је праћен рад књижевника, песника, издавача, новинара, професора. У време владавине цара Павла уведена је ригорозна цензура страних издања те Кошутић запажа: «Праунук зазида оно окно које велики му предак Петар I проби у Јевропу. Китајски зид одели Русију од просвећена света» (1896: 30). Своје искуство са цензуром Кошутић описује са извесном дозом хумора и ироније, показује да се стање није битно променило. Наима, вођен примером Беча, где су српске новине успешно излазиле, Кошутић пише о своме покушају да у лето 1891. у Петрограду покрене илустроване новине на српском језику: «Тисуће претплатника у изгледу, штампа јевтина, хартија још јевтинија, слике буд за шта, а садржај ни за што; за њ би се побринула гомила наших вредних књижевника, тих добрих, у свету јединствених људи, којима је сва награда грдња у оним истим листовима којима су бесплатни сарадници». Цензура није одобрила покретање новина с образложењем «да је Петроград незгодан за тај посао» (Кошутић 1896: 3).

Тема Први руски слависти у нашим крајевима написана је на основу кореспонденције младих научника објављене у часопису Жива старина који је излазио од 1890. године под уредништвом В. И. Ламанског (1833-1914), истакнутог слависте и професора Универзитета у Петрограду. Боравак руских слависта у нашим крајевима везан је за отварање катедри словенских језика и књижевности на руским универзитетима од 1835. године. Стручњака за ове области није било, као ни одговарајуће научне и стручне литературе, те је боравак у словенским земљама и упознавање са њиховим језицима и културама био неопходан. Изабрани су млади стручњаци: Измаил Иванович Срезњевски (1812-1880) испред Универзитета у Харкову, Осип Максимович Бодјански (1808-1877) за московски, Петар Иванович Прејс (1819-1846) за петроградски и Виктор Иванович Григорович (1815-1876) за казански унивезитет. Њихов боравак у словенским земљама и научни радови проистекли из тих путовања, према оцени А. Пипина, значио је прелом у целој словенској филолошкој науци, не само у Русији, него и на Западу. Ламански пише о Прејсу као о првом великом научнику у области упоредне науке о језику, одличном истраживачу словенских старина, а његови чланци о црквено-словенском језику, о глагољици, о бугарском језику, о српској епској поезији важе као узорни радови. Пипин закључује да од радова ове четворице слависта почиње упоредно проучавање словенске филологије у Русији.

У једном од три писма о овој теми Кошутић пише о Прејсовим путовањима, док у два писма преноси утиске Срезњевског. На та путовања обојица су кренули крајем 1839. године, заједно су посетили Лужичке Србе, затим одлазе у Праг и Беч, где се састају са Вуком Караџићем који, према писању Прејса, «беше у Бечу једини ауторитет ком се млади слависти клањају не само као научнику, већ којега поштоваху и као Словенина здравих погледа и љубљаху као светлу личност» (Кошутић 1896: 60). На својим путовањима, заједно или одвојено, руски слависти посетили су многа места у Истри, Далмацији, континенталној Хрватској, Црној Гори и Србији. У својим писмима оба млада научника пишу о гостопримству и гостољубивости на које су наилазили у свим крајевима, градо- 
вима и местима кроз која су пролазили, али и о великом сиромаштву, болестима, заосталости. Разговарали су са владарима, представницима интелигенције, обичним грађанима; у манастирима са свештеним лицима. У време њиховог боравка у Хрватској илирски покрет био је у пуном замаху и они се у Загребу сусрећу са његовим творцима и вођама Људевитом Гајем и Јанком Драшковићем. О утиску из Загреба Прејс пише: „У Загребу раде непрестано две штампарије и излазе двоје новине (политичке и књижевне) на илирском или, што је свеједно, на српском језику; од Нове године удвојиће се број повремених издања; у сваком иоле већем граду отворене су читаонице (има их већ шест), а наскоро ће се овде основати и музеј и уз њега научно-књижевно друштво. Овде се налази и стално илирско позориште, а по варошима путују позоришне дружине“. У Славонском Броду Срезњевски сусреће трговца И. А. Брлића (1795-1885), аутора Илирске граматике (Grammatik der illyrischen Sprache, 1833). Кнез Михаило примио је Прејса у јануару 1843. године, а писмо о том сусрету он завршава речима: «Боже мој, коликим ће се несрећним жртвама морати искупити мир Србији» (Кошутић 1896: 66-68). Писма из Србије Срезњевски упућује мајци па је разумљиво да најчешће пише о свакодневном животу, о српским обичајима приликом дочека гостију, о домаћинима код којих је ноћивао или се хранио, о манастирима Раваници и Манасији. «Србија је дивна земља: плодних поља, шума, виногради, рогате марве, оваца, свиња. <..> На путу стрче само механе, а села су разбацана: овде кућица, онде кућица, две три свега ако се виде у свој околини. <..> То сакривање људских станова без сумње је последица турске управе. И по механама види се да су Турци земљом владали: механе су без столова, и скоро без столица, <..> и сасвим без женске главе», - пише Срезњевски и наставља описом собе у којој ће преноћити: «Замислите коморицу без прозора, коју је на половину запремило сено, покривено ћилимом; место столица мале ниске клупице» (Кошутић 1896: 110-11).

Писма руских слависта сугеришу читаоцу, колико је међу њима био цењен Вук Караџић. Међутим, Кошутић ће пренети о томе и други пример (1895: 186):

«Преврћући један од најстаријих дневних листова руских, Сина Отаџбине за 1889. наиђох у подлистку о бугарској књижевности на овако место:

“Вуко Караџић, славни песник бугарски, први је упознао Јевропу са умотворинама свог народа.”

Како нас Руси дивно знају!»

У време Кошутићевог боравка у Петрограду, Русија је имала шест угледних универзитета: московски, петроградски, казански, кијевски, харковски и новоруски (у Одеси). У свом саставу сваки универзитет имао је историјскофилолошки, физичко-математички и правни факултет; у саставу московског, казанског, кијевског и харковског био је и медицински факултет, док је петроградски имао у свом саставу факултет источних језика. Наставно особље чинило је 251 редовни професор, 116 ванредних професора и 274 доцента (ПГ 1891: 719-20). Па ипак, Кошутић се опредељује да, на основу већ цитиране књиге А. С. Скабичевског, опише «један мрачан лист из историје његове», за време последњих година владавине Александра I. По угледу на Немачку, одређени су посебни чиновници који су контролисали универзитетска предавања, уџбенике 
и рад професора. Под удар цензуре посебно долазе казански и петроградски универзитет, где се масовно отпуштају професори и забрањују уџбеници. «Читајући исказе очевидаца о том суровом моменту руске историје, човек се јежи од страха. Тешко је претпоставити да је светло професорско звање било игде и икад тако понижено и у блато укаљано», наводи Кошутић. Никакви аргументи нису могли помоћи окривљеним професорима, те је запажена духовита реакција младог професора филозофије Гаљича. Уместо одговора, он је испод сваког питања написао: «Сазнајући да се то не да одбацити или опорећи, молим да се не помињу греси младости моје и незнања мога» (Кошутић 1896: 167-9).

На крају овога писма у ПГ налазимо Кошутићева размишљања о природи уметности, једну веома оштру критику савремене српске поезије и критику њеног превођења са руског језика, што је изостављено у књизи (ПГ 1894: 5257). „Под заједничким кровом лепих вештина све гране уметности сливају се у општу, божанску хармонију, ну свака од њих је самостална, свака има своје градиво и своја средства, свака ствара производе, у којима је нешто што се ничим не да заменити, јер је свака лепа својом властитом лепотом“. На питање, куда иде наша савремена поезија, Кошутић одговара да је патила од безидејности, „а сад већ постаје недопустиво бљутава са свог идиотског блаженства и епикурејизма“. Кошутић затим критикује наше слависте због потцењивања превођења са руског језика: „У семинару за словенску филологију они рију као вредне кртице по старим рукописима. $<\ldots>$ Кад им од тог рада дођу виле очима, они, онако прашњавих, незграпних руку, зграбе какав песнички цвет и начине од њега накараду“. Као пример он анализира превод слависте А. Писаревића Пушкиновог Бориса Годунова, наводећи да преводилац слависта нема ни песничког дара, нити познаје језик великог песника.

4.

Заједничка карактеристика писама најављене треће књиге (Последња писма из Петрограда) је њихова усмереност на опис савременог стања. Издваја се неколико основних тема: јубилеј другог одељења Императорске Академије наука, годишња прослава Универзитета у Петрограду, састанак Словенског добротворног друштва, педагошки календар за 1892/3. годину, религија и свештенство као главна и најобимнија тема. Ту су и некролози поводом смрти А. А. Потебње и Н. А. Попова (ПГ 1892: 65-6).

Дана 29. децембра 1891. године славило је друго одељење (Отделение русского языка и словесности) Академије наука своју педесетогодишњицу. Велика сала у старом здању на Васиљевском острву била је пуна високе господе, научника који живе у престоници и људи који се занимају науком. Овако почиње чланак о јубилеју Одељења објављен као друго писмо у два наставка (ПГ 1892: 311-315 и 394-398). Користећи податке из реферата Ј. К. Грота, Кошутић пише о историјату Одељења, истакнутим делатницима, најважнијим издањима. Читалац сазнаје да је Одељење основала Катарина II 1783. године: «да пречишћава, богати и регулише књижевни језик руски». У саставу те прве Академије било је 60 чланова, мада је међу њима било мало правих научника, ипак је релативно брзо испуњен први задатак - састављање речника руског 
језика (1794). Почетком 19. века објављена је граматика, а касније је негована преводилачка делатност. Цар Николај I, незадовољан радом дотадашње Руске академије и Академије наука, 19. октобра 1841. оснива нову академију са три одељења, а међу њима одељење за руски језик и књижевност заузима централно место. Задатак новог одељења био је «да изучава руски и остале словенске језике и да научно разрађује историју руске књижевности». Од 60 чланова пређашње Руске академије 20 је добило звање редовног члана, а остали су постали почасни чланови другог одељења. Први капитални рад био је нови речник црквено-словенског и руског језика (1847), руска граматика академика Давидова (1851), речник под уредништвом Востокова (1852). Историјат Академије даље се описује кроз рад академика А.Х. Востокова, И.И. Срезњевског, Пекарског, Биљарског, Плетњова, А.В. Никиченка, А. Бичкова, М.Ј. Сухомилова, А.Н. Веселовског, В. Јагића. Посебно се разматра рад Одељења и појединих академика у текућој 1891. години. Главни задатак био је рад на новом академском речнику Ј. К. Грота, чији је први том био управо објављен.

Пишући о Јагићу, Коштић наводи да је, као већ познати слависта, примљен у Руску Академију 1880. на место Срезњевског који је те године преминуо. На Јагићев предлог предузело је Одељење изучавање руског језика на плану синхроније и дијахроније и то граматичког и лексичког система. Године 1891. Јагић је објавио делове свог великог рада о црквено-словенском језику у издању Академије, истовремено, ако имамо у виду његове радове који се штампају у Бечу и Загребу и «ново дело што га штампа Јагић у Београду трошком Српске Академије - имаћемо приближан појам о неуморном раду великог слависте» (ПГ 1892: 396). Занимљиво је да Кошутић овде употребљава синтагме «наш славни земљак», «велики слависта», не помињући да је реч о професору, код кога је слушао предавања и пре непуне две године дипломирао.

Ако имамо у виду каснији Кошутићев лексиколошки и лексикографски рад, занимљиво је видети како он описује обим и речнички чланак поменутог речника руског књижевног језика. Речником је обухваћена лексика књижевних дела почев од Ломоносова; из црквено-словенског и старо-руског језика узете су само оне речи које се налазе у књижевним делима или су још у употреби; укључени су и одређени локализми; укључени су општенаучни и технички термини као и речи руског језика које би могле заменити стране термине; у речник су ушле многе позајмљене стране речи; уз ботаничке и зоолошке тремине наведен је готово свуда латински назив, а синоними под којим је нека биљка или животиња позната у разним крајевима Русије штампани су курзивом. Речи које долазе у двојаком облику унете су под оба облика; свака реч је акцентована, ако у флексији акценат прелази на други слог и то је назначено; уз сваку реч налази се кратко граматичко објашњење; семантизација речи врши се у конетксту на примерима узетим из књижевних дела, помоћу пословица и изрека али и примера из разговорног језика.

У наставку Кошутић пише о свечаној академији поводом Дана Универзитета у Петрограду. Те 1891. године на историјско-филолошком, физичко-математичком, правном и факултету источних језика Универзитета радило је 67 професора, 55 доцената и 41 лектор и предавач. Даље се наводе подаци о броју студената, описује опремљеност научних кабинета, издавачка и преводилач- 
ка делатност, додела награда студентима за најбоље научне радове, рад стручних друштава (историјско, нео-филолошко, физичко-хемијско, антрополошко и природњачко), финансијско пословање и др.

Ово друго писмо завршава се извештајем са годишње седнице Словенског добротворног друштва на којој је изабрана посебна комисија за бригу о сиромашним студентима из словенских земаља. Највише студената било је из Србије и Бугарске, а Друштво је имало 39 стипендиста, 6 стипендисткиња, а још 11 студената добијало је помоћ за школарину.

Тему образовања широких слојева руског друштва заокружио је Кошутић анализом савременог стања, тј. последње деценије 19. века (ПГ 1892: 810-819). У то време излазило је више десетина новина и часописа, а само педагошких недељних и месечних часописа било је једанаест. Ова тема инспирисана је садржајем часописа Педагошки календар за школску 1892/3. годину у коме налазимо целокупно школско законодавство Русије, расписе владе о појединим школама и правила за њихов рад, наставне програме различитих школа, статистичке податке о наставницима и ученицима, податке о библиотекама и читањима за народ, књиге које се могу читати народу, приказе најновијих издања педагошке литературе. «То је нешто, што бисмо ми Срби требало апсолутно да издајемо сваке године», констатује Кошутић. У даљем тексту наводе се статистички подаци о броју штампарија и литографија, књижара, библиотека, броју објављених наслова у наведеној години, број дела објављених на руском језику, на другим језицима (највише на пољском и немачком), тираж објављених књига. Тако је у 1890. години периодичних издања изашло је у Русији укупно 748 (ту је и анализа по областима). Даље се наводе статистички подаци о броју школа у претходној години према оснивачу: школе министарства просвете, школе св. Синода, школе војног министарства и школе завода царице Марије. Табеле садрже број ученика и ученица и трошкове појединих школа. Читалац сазнаје податке о укупном броју, образовном профилу и нивоу школских установа појединих оснивача. Министарство просвете оснивач је виших школа и универзитета, института и лицеја, средњих школа (мушких и женских), гимназија, прогимназија и реалки. Ту су подаци о нижим школама по губернијама, основним, приватним и учитељским школама. Напредак школства уочљив је и на основу извештаја о петроградским основним школама за школ. 1891/2. годину, где је «општина прегла, с ретком љубављу и пожртвовањем, око престоничких основних школа, поставивши у комисију за тај рад своје најпросвећеније људе» (ПГ 1892: 816). Резултат је очигледан: док је пре само 15 године било у граду свега 16 школа на скоро милион становника, сада их има 281, и то 153 мушке, 126 женских и две мешовите; петроградски Немци имали су своје посебне школе. Уочен је недостатак средњих школа у престоници.

У посебном поглављу овога писма разматра се положај учитеља у руском друштву, а учитељски позив, према Кошутићу, један је од најтежих позива људске делатности. Многобројне примере налази он у књижевним делима, а исто тако примери жалостне судбине учитеља испунили су периодичну штампу. Само учитељи школа под министарством просвете имају пристојну плату и пензију, док остали раде за ништавну плату и остају без пензије. Преносећи примере из штампе трагичних животних путева сеоских учитеља, Кошутић 
предлаже да сеоске школе добију земљу коју ће учитељи обрађивати и тако обезбедити себи приход и поштовање сељака. Уједно би уводили у село савремене агротехничке мере и унапредили пољопривреду и живот сеоског становништва.

По обиму и дубини обраде, равноправно са темом образовања и просвећивања народа, налази се тема религије и свештенства. Овој теми Кошутић посвећује шест веома студиозних писама: I, XIII, XIV, XVIII, XIX, XX, објављених у ПГ у периоду од 1892. до 1895. године. Православље у години 1888. и 1889. наслов је првог писма (ПГ 1892: 59-66), написаног на основу Извештаја министра црквених дела К. Победоносцева поднетог цару Александру III. Извештај је објављен у Санкт Петербургу 1891. године, а обухватао је широк круг детаљно обрађених тема: свештенство, цркве и манастири, утврђење и ширење православне вере, духовне академије, семинарије и училишта, духовна литература, материјално стање цркве, однос према осталим православним и неправославним црквама и друго. Извештај садржи масу статистичких података и сведочи о напретку православља на многим пољима, посебно од времена када је постало главни стуб и носилац идеје самодржавља. Од 1884. црква оснива своје школе по свим селима и тиме је узела у своје руке највећи део народног образовања. Црква шири књигу у народ, оснива и отвара библиотеке и читаонице, организује дистрибуцију књига духовног садржаја, издржава болнице, домове за сиромашне. Њени мисионари шире православље и тиме раде и на ширењу руског језика и руске државне идеје. Резимирајући своја разматрања места и улоге цркве у руском друштву, Кошутић закључује да се не ради само о напретку цркве него и о просперитету новог правца у унутрашњој политици Русије, стога овај извештај привлачи пажњу и ван њених граница.

Из Извештаја Кошутић преноси низ занимљивости па читалац сазнаје да «од сто милијуна становника, што насељавају огромна пространства руске царевине, православна руска црква бројала је у свом крилу почетком 1889. г. 70\% целог становништва Русије. Одбивши број умрлих од броја новорођених, православно насељење повећало се од 1888. г. за 1.381.380 душа оба пола. Осим тога, из друге вероисповести прешло је исте године 17.357 у православље, а из православља 502 душе у другу веру«. Даље се констатује мањак броја епархија у односу на број становника, будући да епархије обухватају и до милион верника, док у Грчкој тек око 50 хиљада душа. Истиче се културни значај цркве у Русији и мањак броја храмова чак и у Петрограду. Број манастира износио је 691, и то 480 мушких и 211 женских. Ту су подаци о броју црквених библиотека, о духовним издањима; демографски подаци, подаци о броју склопљених бракова и развода.

Посебно се разматрају сва три нивоа духовног образовња. Број слушалаца у све четири духовне академије - петроградској, кијевској, московској и казанској, износио је те године 790, већина је претходно завршила духовну семинарију, но има их из гимназија и реалних школа. Међу страним студентима било је највише Срба (16), затим Бугара (10), шест Румуна, три Јапанца, два Грка, по један Црногорац, Чех, Сиријац, Арапин и један студент из Галиције. Исте године било је 55 богословија које су образовале сеоско свештенство и учитеље, те 184 училишта за основно духовно образовање. Управа духовних школа при св. Синоду обратила је посебну пажњу наставницима на изучавање 
руског и црквенословенског језика: «предавање треба да је кратко, јасно и да не излази ван граница елементарног курса; изучавање граматике да буде практично, мало правила и много примера; правопису да се ученици уче из диктанда» (ПГ 1892: 62).

Тему православља, једног од три стуба руске државности, Кошутић наставља након две године, у тринаестом и четрнаестом писму (ПГ 1894: 251-262, 312 322). Православље је за њега, не само симбол руске државности, него и саставни део руског националног бића: «Вера стоји у Русији на првом месту. Православље се тако уживело с руским народом <..> да је тешко замислити неправославна Руса. Мимо све то, Рус није фанатик у вери, у оном смислу, у ком су Пољаци: толерантан до крајности према толиким вероисповестима које исповедају разни народи опширне руске царевине, он је далеко и од националне мржње према њима, као и наметања им своје вере и својега језика». Суштину бића руског човека Кошутић појашњава поређењем са европским народима:

«Толерантност у Руса долази до равнодушности: хладни по природи, они се тешко одушевљавају за друге. Народи на јевропском западу могу се братимити у име начела напретка и слободе; Рус те појмове тумачи својим особитим начином - за њега је такво братимљење немогућно. Кад неки народ устаје на оружје да се бори против вековне тираније, унапред може знати, где ће наћи одзива. Руси су у питању; борба сама по себи не значи за њих још ништа; да им душу напуне топлија чувства, да се широки њихови слојеви одушеве за тај потлачени народ, треба да знају, које је он вере. Реците им, да је он православан и огромне масе заталасаће се, <..> и пожртвовању неће бити краја; жртве су тако велике, да зачуђена Јевропа због колосалности њихове не верује у искреност њихову; проповедајући идеје једнакости и братства, она није принела ослобођењу подјармљених ни десети део таквих жртава» (ПГ 1894: 251).

Главна тема у оба прилога посвећена је руском сеоском свештенству, тј. верским учитељима народа и носиоцима идеја православља. Кошутић полази од претпоставке да од њихове личности и посвећености служби зависи дубина вере у народу. Као извор грађе за опис типова сеоског свештенства послужиће руска уметничка приповетка јер је она, по Кошутићевом мишљењу, исто тако ангажована као и руски роман и руска књижевна критика; нема ни једне појаве у руском социјалном животу, којој приповетка није ухватила битне црте, указала јој узроке и последице. Идеју је преузео од А. Попова, професора духовне академије, који је издвојио око 20 разних типова свештеника, на основу руске књижевности периода од 1870. до 1884. («Типы духовенства в русской художественной литературе», Казань, 1884). Кошутић је типичне ликове сеоског свештенства нашао у приповеткама објављеним у часописима (Отечественные записки, Вестник Европы, Дело, Век), а као аутори наводе се И. Серов, Р. Сосна, М. Сибирјак, Н. Љесков; у неким случајевима изостало је име аутора. Међу њима издвојио је Кошутић десет типова свештеника, поделио их у две групе: оне које је тежак живот претворио у најамнике свога посла и добре свештенике који познају и воле свој народ.

На примерима јунака приповетке Серова, оца Василија и оца Спиридона, види се, до чега сиромаштво доводи свештеника, примораног да живи од при- 
лога: брига за новац направи од оца Василија тврдицу. Отац Спиридон оличава лењост, а она је «мати свих порока». Отац Андрија није пастир своје парохије, већ најамник, који се стара да што више заради; парохијни су за њега «проклети народ». Отац Стеван псује да га ниједан пијани сељак не може надмашити; «то је био атеист у мантији, слуга олтара у којем није видео Бога». Отац Иван био је сањалица. Отац Андрија Андрејич, млади свештеник, школован: «свршив школу и изневши из опширнога круга наука само одломке, он ступи у живот без икакве озбиљне спреме, без икаквих уверења, с лакомисленим погледом на свет и с високим мишљењем о себи». Отац Георгије представља ново свештенство, млад, углађен, кабинет му је једноставно, елегантно, али сасвим «непоповски» намештен; прилоге је примао само у новцу; свестан је положаја свештенства у друштву: «Прост народ не поштује свештеника због гроша које узима од њега; интелигенција - због непросвећености; трговачки сталеж - због оскудице у самопоштовању».

Мисао Сибирјаковог јунака о материјланом положају руског свештенства појашњава даље Кошутић: «Свештенство треба да буде духовни пастир народу, с којим, због материјалних околности, долази сваки дан у сукоб». Народ се жали на издатке за свештеника и цркву приликом разних верских обреда, причешћа, крштења, венчања, сахрана, помена, слава. «Тако је! одговориће вам свештеник. Ну откуда да живим ја и остало свештенство тога великога храма, којему се толико дивите; откуд да се издржава тај хор, чије вас је појање тако занело; ко да очува лепоту здања у сјају којим сијаше, кад изиђе из руку неимарових? Сем тих прихода, што падају у цркви, у нас није ништа више». А приходе, сматра Кошутић, требало би да обезбеди држава: «Ни у једној јевропској земљи државна власт не ослања се толико на цркву, и нигде у Јевропи држава не даје тако мало за њу као у Русији. С једне стране, православље, стуб државни, а с друге свештенство, представник и ширилац православља, остављено је на милост народу» (ПГ 1894: 259).

У руској уметничкој приповетци Кошутић налази ликове добрих свештеника, као што су отац Павле Покровски, отац Савелије и отац Александар Алмазов, а њихов живот и поимање службе описује у XIV писму (ПГ 1894: 312-322). Пада у очи несразмерност броја једних и других свештеника. Отац Павле је сиромашан сеоски свештеник, син црквењака; сломиле су га тешке материјалне прилике и мрачна средина у којој је живео. Отац Савелије све важније догађаје бележио је у дневник; из очију му светли ум, искреност и смелост: «Само така дубоко хришћанска душа, као што беше у оца Савелија, могла је запазити и искрено се радовати тој безграничној љубави рускога народа према сиротама и несрећнима, као битној црти рускога карактера. Још и сад злочинце послате на заточење у Сибирију, не зове тамошње становништво друкчије, до несрећницима, па и тамо као и у суседним губернијама, свака сељачка кућа оставља на прозор нешто јела ако удари какав залутали бегунац, какав несрећник, да се заложи». Идеални тип сеоског свештеника, према Кошутићу, био је отац Александар Алмазов, предводник новог поколења. У својој парохији отворио је школу, болницу, апотеку, сиротиште, затворио четири од пет крчми, а преосталој одредио годишњи порез. Свештеницима је куповао станове и градио куће. 
Како већина свештеника, посебно старијих, није била на висини свог позива, могуће узроке Кошутић тражи у образовном систему и њиховом школовању. Најбољи одговор пружа аутобиографска приповетка Слике из бурсе Н. Г. Помјаловског коју Кошутић преноси у три последња писма (ПГ 1895: 5364, 359-367, 425-436). Као осмогодишње дете Помјаловски је дошао у бурсу, тј. интернат уз духовне школе, где су ђаци имали обезбеђен смештај, храну и одећу. Након осам година из те школе прешао је 1851. у богословију, где се школовао шест година, али је пресудну улогу у његовом образовању одиграло самообразовање. Преминуо је у 29. години живота. У првом писму даје се подробна биографија младог писца, док друга два писма садрже готово без коментара превод приповетке, са крајње негативним описом услова живота и образовања у верским школама. «Тако описује Помјаловски стару семинарију. Нека читалац пређе у памети све те слике, па ће му бити јасан још један узрок, зашто је старо руско свештенство било онако немарно, сурово, тупо и дивље», закључује Кошутић ову тему.

У другом делу XIV писма Кошутић износи веома оштру критику свештенста у Србији, образлаже зашто свештеник не може да се бави политиком и предлаже којим путем треба ићи. «Шта раде наши свештеници, слободни од већине препрека које тиште браћу им у Русији? Ништа! Већа их половина изметнула се у просту гомилу лењиваца која живи само да једе, која је подивљала, отупела». Из извештаја митрополита Михаила за 1893. г. сазнаје се да многи људи не умеју ни да се правилно прекрсте, данас, много векова «од како св. Сава унесе хришћанску веру међу витешке претке наше. <..> Реч којом свештеник утиче на народ, може стајати само на јеванђељској основици, може истицати само из науке Спаситељеве, а не из политичких чланака разних новина. Код нас мисле друкчије. Зато су храмови празни, а крчме пуне, вера пада, а безбожништво расте, име Божије употребљава се већином за псовку. Где смо ми и куда идемо?» Бавећи се политиком, наши свештеници «хватају се за разне политичке теорије, од којих ће свака са временом постати лаж, да уступи место новој, коју чека та иста судбина». У политичком животу то је оправдано, али цркви није место у том колу. Уколико се свештеник бави политиком, он неминовно дели вернике и окреће их једне против дргих. «Свештеник има пред собом само парохијане свог села, само чланове једне духовне општине, $<\ldots>$ a не чланове разних политичких странака. <..> Како то да се код нас једном не увиди, да се политика уопште не слаже са свештеничким позивом, тј. да свештеник не може ни бирати, ни бити изабран. <..> Држава му може пружити сва права, која даје свима грађанима, ну свештенство може примити само она, која се не косе с позивом његовим. <...> Напоље, дакле, из политике са свима, од највиших до најнижих, који служе олтару Божијем, и напоље с политиком из цркве». Даље Кошутић износи своје мишљење о дужностима свештеника: «Свештеник ће држати недељом и празником проповеди у храму божијем; а после ручка, у благе дане, скупљаће народ у школско здање, било да му држи предавање, било да му чита поучне књиге, које прост човек не може сам прочитати, будући је неписмен. Он ће отварати сеоске библиотеке и биће моћан чинилац у ширењу просвете народне, памтећи да непросвећен човек не може љубити свог ближњег, гледати брата у њему и праштати му, јер је тамна душа 
његова робиња свакојаком залуђивању. <..> Сећајући се “да истинско религиозно васпитање заузима најважније место у свеколиком васпитању човечјем”, свештеник не само што ће у школи учити децу закону божјем, већ ће их водити тим путем и кад изиђу из ње, дајући им својим животом пример, како треба живети по правилима хришћанске наравствености». Своја размишљања о свештенству Кошутић завршава рекло би се пророчанским речима: «Ако се овај део свештенства, што ништа не ради, не сети, да је вера без дела шупља љуска, тј. да је мртва; а овај што проповеда «око за око, зуб за зуб» и даље пође с једном половином стада против друге, измаћи ће му се и прва из руку, и коначан пад вере биће само питање времена» (ПГ 1894: 320-2).

5.

О Петрограду Кошутић пише у каснијем периоду боравка у томе граду и то кроз две главне теме: годишња доба (Петроград зими, Петроград лети, Јесен у Петрограду) и празници (Дечја јелка у Петрограду, Покладе у Петрограду, Ускрс у Петрограду). У овим поетски надахнутим текстовима опсују се најважнији обичаји који прате верске светковине у граду, од хране, пића, уређења дома, духовног прочишћења, од појединца, породице до читаве заједнице. При томе Кошутић врло често износи своја запажања о неким типолошким карактеристикама и особеностима руског националног карактера. Кошутић није само посматрач већ живи учесник у тим догађањима.

Као контраст суморном зимском дану следи бајковит опис прославе Божића: окићена јелка у велокој општинској сали, узбудљиви жагор деце и њихових родитеља, музика изводи омиљене песме, игре на срећу, изложба дечјих радова, дечја лутрија. «Једна млада госпођа искупила гомилу сироте деце, па им купије разне ствари; десетица отиће јој зацело. Нигде нема тако добродушна света као у Русији», закључује Кошутић (1896: 102). Сличну особину на колективном нивоу у време велике глади показали су житељи средишње Русије, где је у то време живело 30 милиона станоника. Њихов поступак оценио је Кошутић као поучан и дирљив пример како се целокупно становништво заложило да помогне сиромашнима, посебно школама и ђацима. „Најшира дарежљивост <...> обухватила је све слојеве руског друштва. Такве жртве ретко приносе и најпросвећенији народи“"(1895: 99).

Исто тако сликовито описује се богојављењска свечаност на Неви, затим прослава Поклада, а она се, због сурове климе на северу, разликује од прославе у другим крајевима: «Да раздрма ту тешку, успавану природу своју, северни становник треба много да попије. Нама је доста чаша, две вина; Русу је мало две три чаше ракије, и то оне руске, двапут јаче од наше». Нешто даље у истом тексту, описујући брзе тројке Кошутић објашњава: «Рус је по природи тих као тихо море, али кад се разигра, онда не зна за границе». Кошутић са пажњом слуша вашарске забављаче и констатује да су пуни «чисто народног хумора, груба, претерана, али врло карактеристична, хумора из којег се види шта запиње за очи простом човеку и шта он налази да треба исмејати». Описујући завршетак светковина Кошутић размишља: «Недеља је последњи дан весеља - они испраћају покладе. Сутра рано свет ће поћи у бање да спере прљавштину с тела, а око десет часова цркве ће бити дупком пуне. Народ ће палити свеће пред ико- 
нама, падаће на колена, ударати челом о хладни мрамор храма Божјег и постиће најстроже седам недеља, молећи се Свевишњем онако како му се само у Русији знају молити. За чудо побожни људи!» (Кошутић 1896: 126-136). И код описа Ускршњих светковина Кошутић наглашава посвећеност Руса цркви и вери јер «није доста ишчистити само станове, већ треба и чисте душе дочекати светли ускршњи празник, па људи врве у цркву, као ваљда нигде на свету. Храмови не могу да приме на бденије све те побожне душе, и огромне гомиле стоје под ведрим небом» (1895: 244).

Инспирисан сликом Петрограда у различитим годишњим добима, Кошутић износи своја запажања о начину живота његових житеља. Поетску слику града прекривеног ињем, снегом, ледом и обасјаног зимским сунцем наставља: «Руси се не састају као ми у кафанама, већ у домовима добрих познаника и пријатеља. Свака породица има одређено вече у недељи, кад је полазе знанци и родбина. Уз чашу чаја ту тече пријатан разговор до поноћи. Зими су сјајне игранке и концерти; онда се дају представе у позориштима, онда се разлежу звуци у опери. <...> Онда се свет стиче на предавања, онда су отворени музеји и царске галерије слика у Ермитажу». Петроград лети изгледа сасвим другачије: «кад спадне зимско рухо, све је изгубљено. Да ужасне вароши! Врућина је, сунце скоро никад не залази. Праве, широке улице отегле се у бестраг; нигде дрвцета да их зачини, да пружи мало хладовине. Да шарених кућа! Отворено плава, жута или црвена, <..> не зна се која је већа од које и која је саграђена с мање укуса. Архитектонски украси ту су још непознати. Стил касарна - то је петроградски стил» (Кошутић 1896: 47-50).

Посебно поглавље посвећено је светковинама на селу, народним обичајима, веровањима и обредима везаним за обележавање празника. Сликовито се описују обреди и обичаји везани за испраћај зиме и долазак пролећа, прослава Поклада, Ускрса и обичаји током Томине недеље, почетак пољских радова, обредне песме девојака, ратара и пастира. Дивећи се руским обичајима, Кошутић ипак оцењује да је прослава Ускрса код нас и лепша и духовнија. Исто тако наши божићни обичаји су лепши од руских: Руси не уносе сламу у кућу, не пале бадњаке, не секу божићни колач, не ломе чесницу, не поздрављају огњем из пушака рођење Бога светлости (Кошутић 1895: 134). Традицију и обичаје руског села приближиће Кошутић српском читаоцу користећи релевантну литературу из компаративне митологије (А. Афанасьев, Поэтические воззрения славян на природу) и наћи заједничке црте кроз причу о прослави Ђурђевдана и веровању да гладан вук иде светом Ђурђу да од њега добије «суђену» овцу, а мимо воље свеца да не може ни једну овцу заклати. Тако је настала пословица: «Што је вуку на зубима, то му је Ђурђе дао»; у српским селима обичај је да се за овај празник коље јагње. У погодним приликама објашњавају се и друге руске пословице: Од свога одустао, уз туђе не пристао; Каквом мером мериш, таквом ће ти се мерити; Нема зла без добра; Где је танко, тамо се и кида; Љубав није пожар, загори ли, не можеш је угасити.

На различитим местима искрсава понеки аутобиографски податак везан за Кошутићево детињство и школовање. Тако суморни јесењи дани у Петрограду буде у пишчевом сећању слику јесени у родном Срему. Јесен његовог детињства је најлепше и највеселије годишње доба; берба грожђа на Фрушкој, уз красне 
напеве наших песама, ређају се здравице. «Бејах мало дете, кад ме отац доведе у Карловце, у гимназију. Кад бесмо Дунаву на догледу, рече ми: „Чувај га се; тај гута децу кад се купају!“ Ја сам се дивио великој реци, грдосији према малим гатовима рођеног места мога. Па Фрушка! Тек ту се видела лепота и висина те красне горе, хранитељке гладних ђака у толиким приликама. Моја газдарица, стара нека бака, код које сам имао за осам форината и стан и храну и огрев, частила ме је увек пасуљем. Свако јутро, кад сам полазио у школу, стара душа испраћала би ме речима: Данас ћемо жутог! На моју несрећу, жути тачканац беше те године као буба родио у њезину винограду, па га је непрестано кухала, то ми поштено додија. - А како би било белог, приметих јој бојажљиво. - Па добро, синко, данас ћемо белог, пристајаше она великодушно.

Гладне браће као ја нашло се повише; дубоко у јесен, ми, свега жељни, увлачили бисмо се у винограде да пабирчимо оне звонцади, незреле у време бербе, и да нађемо какав гроздак, који је превидела берачица» (Кошутић 1896: 186-7).

Пишући о руској гимназији Кошутић се сећа свога професора немачког и латинског језика, Марка Маринковића и своје гимназије: «Мени излази пред очи карловачка гимназија крајем 70-их година, она стара побаушена зграда с жељезним решеткама на прозорима, са зеленим капцима на лабавим шаркама. Као да сад гледам нас малишане, синове сиромашних српских занатлија, искупљене око топле гвоздене пећи» (1896: 17).

Цртица Како се пате наши ђации у туђини такође може бити аутобиографског карактера. Записана је по речима «једног пријатеља» који је, као и Кошутић, у јесен 1887. дошао у Лавов да настави своје студије пољске књижевности и научи малоруски (украјински) језик. Хранио се у народној кухињи и добротворном друштву, али најчешће је гладовао, живео на хлебу и води (Кошутић 1896: 19-24).

О материјалним и другим проблемима који прате наше студенте Кошутић поново пише у 19. писму под називом Српски углед у Петрограду (ПГ 1895: 365-7). Он наводи да вођени различитим разлозима сваке године у Петроград долази много нашег света, без икаквих средстава за живот. То су углавном несвршени ученици средњих школа, без потребних знања за наставак школовања. Они штете нашем угледу и националном достојанству. Добре студенте, поред ниских стипендија, мучи непризнавање наших средњошколских диплома у Русији. Наиме, по окончању студија не добијају дипломе, пошто у сведочанству средње школе немају положене грчки и руски језик. Стога Кошутић апелује на наше власти да се ангажују «да наша матура не значи у Русији мање него у осталим земљама». Сматрао је да само најбољи наши ђаци треба да се школују у Русији о чему је као универзитетски наставник писао Шахматову 1909. године (Греков /ред./ 1948: 298).

Сумирајући анализу Писама данашњи читалац остаје затечен сликом руске културе коју Кошутић преноси српском народу, користећи неку врсту епистоларног жанра у коме се преплићу документарност, књижевни и преводилачки поступак. Намеће се питање, чиме се аутор руководио бележећи ,значајне појаве на пољу културног живота руског“, боравећи у Петрограду почетком последње деценије златног века руске културе, што је у Писмима једва назна- 
чено. Да ли је био сувише близу да би могао сагледати његове блиставе домете на пољу руске књижевности, музике, сликарства, филозофије или је његов избор био намеран.

Нема сумње да је своју необичну студију Кошутић посветио руском народу у уверњу да само из народне културе могу настати велика уметничка дела. Руски народ, како га описује млади писац, красе основни хришћански идеали, дубока и искрена вера у Бога, скромност, човекољубље, саосећајност, спремност да се жртвује. Ове особине, као и тежња за образовањм и просвећивањем, заузимају централно место и у историјској вертикали развоја руског друштва. Велика руска књижевност није нашла пут до народа, па је изостала и у овој студији. У више прилога Кошутић анализира дела другоразредних писаца и литературу која се продавала на вашарима уз кућне потрепштине; народ је прихватао јер није имао избора. Ипак, не може се рећи да је Кошутић идеализовао руски народ: на више места налазе се описи сурових поступака појединаца и тамних страна народног живота. Правдао је то вековним тегобним животом, празноверјем и необразовањем.

Ову оригиналну студију, организовану у 24 писма, упутио је аутор српској јавности, у првом реду образовним представницима друштва, интелигенцији, свештенству, образованим девојкама и женама, да се сви, следећи пример Русије, посвете образовању и просвећивању српског народа. Колико је то важно показују статистички подаци о стању писмености у Европи које Кошутић преноси из руске штампе. Број неписмених се кретао од 4 процента у Норвешкој, 9 у Енглеској, преко Аустрије са 23 и Италије са 42 процента, до Русије и Србије са 78, односно 79 процената неписмених. Иза нас су Румунија и Бугарска са 82, односно 85 процената неписменог становништва. „Ја не знам важнијег министарства у Србији од министарства просвете“, закључује Кошутић (ПГ 1894: 50). На другом месту овај велики родољуб пише: „Знате ли како изгледа Србија? Под кровом новог Устава, то је споља дивна зграда у најмодернијем стилу. Но унутрашњи намештај не одговара спољашњој лепоти. Прионимо сви, и мушко и женско, да је удесимо и наместимо тако, како би унутрашњост сјајној спољашњости не само одговарала, већ је и надмашила!“ (ПГ 1894: 104).

\section{Цитирана литература}

Дамљановић, Дара. Руски језик у Србији: уџбеници до 1941. године. Београд: Филозофски факултет, 2000.

[Damljanović, Dara. Ruski jezik u Srbiji: udžbenici do 1941. godine. Beograd: Filozofski fakultet, 2000]

Документы к истории славяноведения в России (1850-1912). Под ред. академика Б.Д. Грекова. Москва-Ленинград, 1948, 297-298.

[Dokumenty k istorii slavianovedeniia v Rossii (1850-1912). Pod red. akad. B. D. Grekova. Moskva - Leningrad, 1948, 297-298]

Кончаревић, Ксенија. „Рецепција дела Радована Кошутића у новијој русистичкој лингводидактици (о стопедесетгодишњици рођења)“. Славистика XX, (2016), 358364. 
[Končarević, Ksenija. „Recepcija dela Radovana Košutića u novijoj rusističkoj lingvodidaktici (o stopedesetgodišnjici rođenja)“. Slavistika XX, (2016), 35-364]

Кошутић, Радован. „А.Н. Пыпин, История русской этнографии I-IV“, Спб. 1890 1892. - Просветни гласник, 1892, 224-228, 295-299, 384-391, 482-485, 564-570.

[Košutić, Radovan. „A.N. Pypin, Istoriia russkoj etnografii I-IV“, Spb. 1890-1892. Prosvetni glasnik, 1892, 224-228, 295-299, 384-391, 482-485, 564-570]

Кошутић, Радован. Нова писма из Петрограда. Београд, 1896.

[Košutić, Radovan. Nova pisma iz Petrograda. Beograd, 1896]

Кошутић, Радован. Писма из Петрограда. Београд, 1895.

[Košutić, Radovan. Pisma iz Petrograda. Beograd, 1895]

Кошутић, Радован. „Писма из Петрограда“. Просветни гласник,1891, I (654659), II (703-710); 1892, III (43-50), IV (129-138); 1892, I (59-66), II (311-315, 394 398), III (485-491), IV (810-819), V (897-905); 1893, VI (277-286), VII (286-293), VIII (356-366); 1894, IX (44-50), X (89-97), XI (97-104), XII (193-203), XIII (251262), XIV (312-322), XV (378-390), XVI (459-472), XVII (516-527); 1895, XVIII (53-64), XIX (359-367), XX (425-436).

[Košutić, Radovan. „Pisma iz Petrograda“. Prosvetni glasnik,1891, I (654-659), II (703-710); 1892, III (43-50), IV (129-138); 1892, I (59-66), II (311-315, 394-398), III (485-491), IV (810-819), V (897-905); 1893, VI (277-286), VII (286-293), VIII (356366); 1894, IX (44-50), X (89-97), XI (97-104), XII (193-203), XIII (251-262), XIV (312-322), XV (378-390), XVI (459-472), XVII (516-527); 1895, XVIII (53-64), XIX (359-367), XX (425-436)]

Лалић, Радован. „Катедра за источне и западне словенске језике и књижевности““. Сто година Филозофског факултета, Београд: Народна књига, 1963, 375-400.

[Lalić, Radovan. „Katedra za istočne i zapadne slovenske jezike i književnosti“. Sto godina Filozofskog fakulteta, Beograd: Narodna knjiga, 1963, 375-400]

Поповић, Богдан. „Реферат о књизи Узроци препорођају књижевне критике“. Просветни гласник, 1895, 266-267.

[Popović, Bogdan. „Referat o knjizi Uzroci preporođaju književne kritike“. Prosvetni glasnik, 1895, 266-267]

Терзић, Богдан. „Културолошки аспекат Кошутићевих Писама из Петрограда (поводом 140-годишњице рођења Р. Кошутића)“. Славистика, X (2006), 25-31.

[Terzić, Bogdan. „Kulturološki aspekat Košutićevih Pisama iz Petrograda (povodom 140-godišnjice rođenja R. Košutića)“. Slavistika, X (2006), 25-31]

Терзић, Богдан. „Савременици о Кошутићу као русисти“.- Славистички зборник, књ.1, Београд,1986, Гл. уред. Р. Маројевић, 21-30.

[Terzić, Bogdan. „Savremenici o Košutiću kao rusisti“.- Slavistički zbornik, 1, Beograd, 1986, Gl. ured. R. Marojević, 21-30]

Тарановски, Кирил. “Радован Кошутић (1866-1949)“„Јужнословенски филолог, 1949/50, 18, 512-517.

[Taranovski, Kiril. "Radovan Košutić (1866-1949)“, Južnoslovenski filolog, 1949/50, $18,512-517]$

Jagić, Vatroslav. Izabrani kraći spisi. Zagreb: Matica hrvatska, 1948, 518-520.

Konstantinović, Radomir. Biće i jezik. Beograd, 1983. 
Дара Дамлянович

\section{ПИСЬМА ИЗ ПЕТРОГРАДА РАДОВАНА КОШУТИЧА}

\section{Резюме}

В статье анализируется культурологический труд Кошутича, опубликованный в 24 письмах в журнале «Просветни гласник» с 1891 по 1895 гг. В Письмах содержатся богатые литературные, культурологические, исторические и бытовые данные, изображающие эпоху и жизнь русского народа. В то же время, Письма являются источником для определения и понимания личности, взглядов, мировоззрения и творческих стремлений автора. В полном объеме данная работа до сих пор не была предметом исследования.

Ключевые слова: Радован Кошутич, Письма из Петрограда, русский народ, сербский народ, культурологическое наследие. 